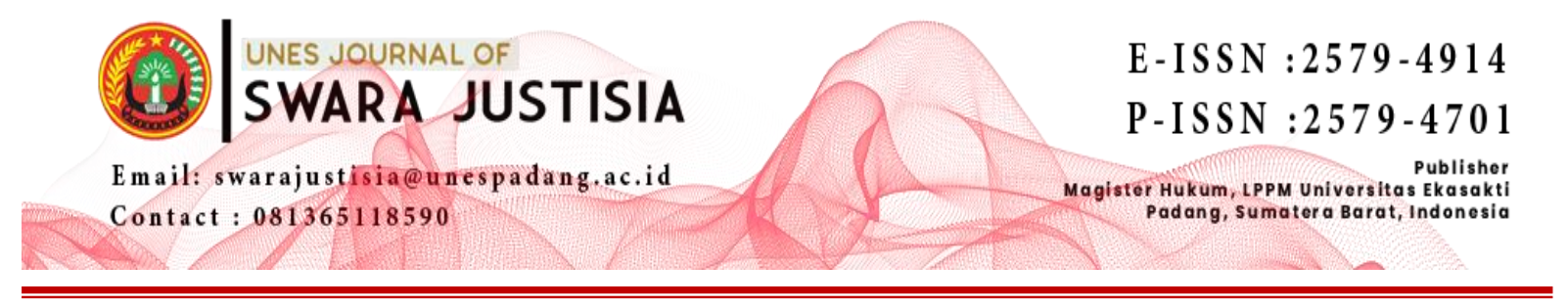

\title{
PENEGAKAN HUKUM BAGI PELAKU TINDAK PIDANA PEMBUNUHAN DALAM PEMBELAAN TERPAKSA
}

\author{
${ }^{1)}$ Julaiddin, ${ }^{2)}$ Rangga Prayitno \\ ${ }^{1)}$ Fakultas Hukum, Universitas Ekasakti, Padang, Indonesia \\ Email: julaiddinmr@gmail.com \\ ${ }^{2)}$ Program Magister Ilmu Hukum, Universitas Ekasakti, Padang, Indonesia \\ Email: ranggaprayitno@gmail.com
}

\begin{abstract}
The value of justice is indeed abstract and can be a benchmark for the consideration of justice of each person is different. Depends on the value that bases its paradigm on justice itself. However, in practice there are still many violations and deviations from the purpose of the law itself, both intentional and unintentional. The role of law enforcement should be to carry out their duties in accordance with applicable provisions. The crime of murder in a forced defense, explaining an act of murder which is clear in the end has severe sanctions, both Indonesian criminal law. Therefore from the existence of compulsion or force impulse which is the reason for the eradication of criminal acts in bringing up a criminal act of murder, whether in the end was punished as a justification or forgiveness in Indonesian criminal law.
\end{abstract}

Keywords: Law Enforcement, Murder Crimes, Forced Defenses, Positive Law

\section{ABSTRAK}

Nilai keadilan memanglah bersifat abstrak dan bisa jadi tolak ukur pertimbangan keadilan setiap orang berbeda-beda. Tergantung pada nilai yang mendasarkan paradigmanya atas keadilan itu sendiri. Akan tetapi dalam pratiknya masih banyak ditemukan pelanggaranpelanggaran serta penyimpangan-penyimpangan terhadap tujuan hukum itu sendiri, baik disengaja maupun tidak disengaja. Sudah semestinya peran penegak hukum melaksanakan tugasnya sesuai dengan ketentuan-ketentuan yang berlaku. Tindak pidana pembunuhan dalam pembelaan terpaksa, menjelaskan suatu tindak pidana pembunuhan yang sudah jelas pada akhirnya memiliki sanksi yang berat, baik itu hukum pidana Indonesia. Maka dari itu dengan adanya keterpaksaan atau dorongan daya paksa yang menjadi alasan penghapus tindak pidana dalam memunculkan suatu tindak pidana pembunuhan apakah pada akhirnya dihukumi menjadi suatu alasan pembenar ataukah pemaaf dalam hukum pidana Indonesia.

Kata Kunci: Penegakan Hukum, Tindak Pidana Pembunuhan, Pembelaan Terpaksa, Hukum Positif

\section{PENDAHULUAN}

Pada asasnya hukum bertujuan untuk melindungi kepentingan korban maupun pelaku, sehingga esensi kepastian, kemanfaatan dan keadilan sebagai tujuan hukum dapat terwujud dengan baik. Tetapi, tidak jarang ditemui beberapa kasus yang dirasa menciderai 
rasa "keadilan". Nilai keadilan memanglah bersifat abstrak dan bisa jadi tolak ukur pertimbangan keadilan setiap orang berbeda-beda. Tergantung pada nilai yang mendasarkan paradigmanya atas keadilan itu sendiri. Hal tersebut juga berlaku bagi aparat penegak hukum yang memiliki dasar paradigma tersendiri mengenai suatu persoalan hukum dan keadilan. Penegakan hukum merupakan suatu usaha untuk menanggulangi kejahatan secara rasional, memenuhi rasa keadilan dan berdaya guna (Julaiddin, 2018). Keadilan menjadi penekanan dalam sebuah negara hukum (Julaiddin \& Sari, 2019).

Akan tetapi dalam pratiknya masih banyak ditemukan pelanggaran-pelanggaran serta penyimpangan-penyimpangan terhadap tujuan hukum itu sendiri, baik disengaja maupun tidak disengaja. Sudah semestinya peran penegak hukum melaksanakan tugasnya sesuai dengan ketentuan-ketentuan yang berlaku (Hutabarat, 1985). Hukum pidana sebagai realisasi kaidah-kaidah hukum yang dibentuk atau dibuat manusia dan untuk mengatur manusia itu sendiri dalam hal ini yang mengatur tentang pelanggaran-pelanggaran dan kejahatan-kejahatan terhadap kepentingan umum, perbuatan mana diancam dengan hukuman sebagai pertanggung jawaban dari perbuatannya.

Pembelaan diri adalah merupakan salah satu hak dan kewajiban yang diberikan Undang-undang kepada setiap orang untuk memelihara keselamatan hidupnya, baik keselamatan jiwa, harta benda maupun kehormatanya. Dan pada dasarnaya pembelaan diri merupakan hak yang menjadi naluri setiap orang untuk mempertahankan dirinya atau orang lain, harta benda dan kehormatanya dari perbuatan jahat pihak lain, yang hendak merusak atau merugikan secara melawan hukum.

Dalam praktiknya upaya pembelaan diri dalam suatu tindak pidana memang tidak selalu mudah. Hal ini didasarkan pada acuan asas proporsionalitas atau keseimbangan, bahwa suatu upaya pembelaan diri harus seimbang dengan ancaman yang akan datang atau sedang berlangsung. Sebagaimana disampaikan oleh Prof. Wirjono Prodjodikoro dalam bukunya Asas-Asas Hukum Pidana di Indonesia, bahwa ukuran proporsionalitas memang tidak memiliki ukuran baku karena penilaian setiap orang bisa jadi berbeda-beda dan dipengaruhi kondisi sosial-kultural dimana tindak pidana itu terjadi (Prodjodikoro, 2003).

Sehingga dalam hal menentukan apakah suatu pembelaan diri tersebut sah secara hukum sebagaimana diatur dalam Pasal 49 Ayat (1) KUHP atau malah termasuk suatu "pembelaan yang melebihi batas (noodweer exces)". Dalam kasus Eko Sulistiono yang merupakan satpam PCS PT Pelindo II cabang Teluk Bayur yang sedang melakukan patroli di lokasi dan melihat korban Adek Firdaus berjalan mengarah dan masuk ke area mess PT CSK. Satpam kemudian meneriaki korban dan menyuruh turun. Korban pun turun dengan wajah emosi dan mengeluarkan senjata tajam, sehingga terjadi pertengkaran yang dilanjutkan dengan perkelahian, yang mengakibatkan korban Adek Firdaus meninggal dunia.

Kronologis tersebut menggambarkan peristiwa terjadinya pembunuhan karena membela diri tertuju pada jiwa. Berkaitan dengan hal itu, maka pemidanaan yang difoniskan tentunya perlu ada kecermatan. Mengingat pelaku menghilangkan nyawa tidak lain untuk mempertahankan nyawanya sendiri. Selain itu pelaku pada mulanya tidak ada niat ataupun rencana untuk membunuh, namun ia melakukannya karena adanya daya paksa.

Secara sederhana pembelaan diri melampaui batas tersebut apabila keseimbangan dalam hal pembelaan diri dilakukan secara berlebihan. Meskipun begitu pembelaan melampaui batas tetap mendapatkan perlindungan hukum sebagaimana diatur dalam Pasal 49 
Ayat (2) KUHP, hal tersebut didasarkan pada adanya perasaan berupa emosi ketakutan, amarah, kebingungan akibat serangan terhadapnya yang bereaksi pada upaya pembelaan yang melebihi batas. Perlu kecermatan dalam menilai apakah suatu tindakan pembelaan dapat dikategorikan sebagai pembelaan diri melampaui batas yang diperbolehkan atau dilarang.

Berdasarkan uraian kasus diatas penulis tertarik untuk membahas tulisan ini dalam beberapa permasalahan yaitu bagaimana pengaturan hukum terhadap pembelaan terpaksa sebagai alasan penghapusan penuntutan pidana.

\section{METODE PENELITIAN}

Metode yang digunakan dalam penelitian ini adalah analisis isi atau content analysis, yang menggunakan data sekunder yaitu penelitian yang bersifat pembahasan mendalam terhadap isi suatu dokumen tertulis baik dari buku maupun tulisan ilmiah lainnya yang relevan dengan pengaturan hukum pidana.

\section{HASIL DAN PEMBAHASAN}

\section{Penegakan Hukum Bagi Pelaku Tindak Pidana Pembunuhan dalam Pembelaan terpaksa}

Pada prinsipnya, hukum pidana adalah untuk mencari kebenaran materiil yaitu kebenaran yang sesungguhnya mengenai siapa pelaku tindak pidana yang sesungguhnya yang seharusnya dituntut dan didakwa. Untuk tujuan itulah pihak kepolisian harus melakukan penyelidikan dan penyidikan. Jadi, sangat dimungkinkan seorang tersangka kemudian ditahan untuk kepentingan penyidikan (dasar hukumnya: Pasal 20 KUHAP).

Pada dasarnya, sesuai dengan asas legalitas, setiap perbuatan tidak dapat dipidana kecuali ada peraturan perundang-undangan yang telah mengaturnya terlebih dahulu (Pasal 1 ayat (1) KUHP). Secara a contrario dapat diartikan bahwa setiap perbuatan yang telah ditentukan merupakan perbuatan pidana dalam peraturan perundang-undangan, dapat dipidana. Dalam KUHP tidak ditentukan dan dijelaskan pengertian pembelaan terpaksa dan apakah pembelaan merupakan hak atau kewajiban seseorang. Tetapi oleh ahli hukum, dijelaskan secara rinci mengenai apa yang dimaksud pembelaan terpaksa ini. Karena dalam pasal tersebut hanya menyebutkan tindak pidana "barang siapa yang melakukan pembelaan terpaksa", dalam keadaan seketika itu karena adanya sifat terpaksa atau terdorong oleh situasi yang darurat atau mendesak dan bukan merupakan anjuran atau perintah.

Pembelaan terpaksa (noodweer) adalah suatu rechtsverdediging yakni sebagai suatu hak untuk memberikan perlawanan hukum. Perlawanan tersebut dipandang sebagai retchmating atau dipandang sah menurut hukum bukan karena orang yang mendapat serangan itu telah melakukan suatu pembelaan, melainkan karena pembelaan dirinya itu merupakan suatu rechtsverdediging, karena dengan adanya serangan kita mempunyai hak untuk melawan untuk melindungi diri sendiri atau orang lain (Lamintang, 2014).

Ditinjau dari segi ajaran atau pandangan monistis tentang delik, maka dalam hal adanya noodweer, perbuatan itu dianggap tidak memenuhi unsur melawan hukum, sedangkan pada noodweerexes, perbuatan pidana tetap ada, tetapi unsur bertanggungjawab pidana, yakni kesalahan pembuat terhapus. Secara ringkas dan sederhana pembelaan terpaksa dan perlampuan pembelaan terpaksa dapat dibedakan sebagai berikut: Noodweer ialah pembelaan 
yang diberikan karena sangat mendesak terhadap penyerangan yang mendadak dan tiba-tiba serta mengancam dan melawan hukum. Unsur-unsurnya ialah:

a. penyerangan yang nyata-nyata:

1) melawan hukum

2) mendesak dan sekonyong- konyong mengancam.

b. penyerangan itu harus mengenai:

1) badan (lijf) sendiri atau orang lain

2) kehormatan kesusilaan (eerbaarheid)

3) atau barang (goed) yang diserang atau orang lain.

Dengan demikian pembelaan itu harus membela diri atau orang lain dan melindungi harta benda dan kesusilaan dalam keadaan terpaksa, sebagaimana dalam kasus satpam PCS PT Pelindo II cabang Teluk Bayur jika tidak melawan kehendak si korban maka akan beresiko mati terkena senjata tajam.

Pengaturan Pembelaan Terpaksa (Noodweer) Dalam Hukum Positif

Dalam sistem hukum pidana positif (KUHP), pelaku tindak pidana tidak dapat dikenakan pidana apabila tidak dapat dasar peniadaan pidana sebagai berikut (Moeljatno, 1993):

a. Alasan yang membenarkan atau menghalalkan perbuatan pidana, adalah (Hamzah, 2004):

1) Keperluan membela diri atau noodweer (pasal 49 ayat $1 \mathrm{KUHP}$ );

2) Melaksanakan ketentuan undang-undang (pasal 50 KUHP);

3) Melaksanakan perintah jabatan yang diberikan oleh seorang penguasa yang berwenang (pasal 51 ayat $1 \mathrm{KUHP}$ )

Ketiga alasan ini menghilangkan sifat melawan hukum dari suatu tindakan sehingga perbuatan si pelaku menjadi diperbolehkan.

b. Alasan yang memaafkan pelaku, hal ini termuat dalam:

1) Pasal 44 ayat 1 KUHP, yang menyatakan seseorang tidak dapat dipertanggungjawabkan perbuatannya, disebabkan jiwanya cacat dalam tubuhnya (gebrekkigeontwikkeling) atau terganggu karena penyakit;

2) Pasal 48 KUHP, yang menyatakan seorang yang melakukan perbuatan karena pengaruh daya paksa, tidak dipidana;

3) Pasal 49 ayat 2 KUHP, menyatakan bahwa pembelaan terpaksa yang melampaui batas, yang langsung disebabkan oleh kegoncangan jiwa yang hebat karena serangan atau ancaman serangan itu, tidak dipidana;

4) Pasal 51 ayat 1 KUHP, yang menyatakan terhapusnya pidana karena perintah jabatan tanpa wenang, jika yang diperintah dengan i'tikad baik mengira bahwa perintah diberikan dengan wenang, dan pelaksanaannya termasuk dalam lingkungan. Dua keadaan jiwa sebagaimana disebut dalam pasal 44 ayat 1 adalah keadaan jiwa sebagai penyebab tidak dapat dipertanggungjawbkannya atas semua perbuatannya.

c. Alasan pengahpusan pidana

1) Pemaaf dalam pasal 44 KUHP tidak mampu bertanggung jawab, adaya daya paksaan/darurat, pembelaan terpaksa.

2) Pembenar dalam pasal 49, 50, 51 KUHP dengan keadaan darurat, pembelaan terpaksa, ketentuan undang-undang. 
Dalam noodweer mengandung asas subsidariteit yaitu harus adanya keseimbangan antara kepentingan yang dibela, cara yang dipakai dan kepentingan yang dikorbankan, maka yang diserang tidak boleh menggunakan cara yang memberikan kerugian lebih besar pada penyerang, dengan kata lain pembelaan yang diberikan tidak boleh melampaui batas (Abidin Farid, 2007). Dan asas propositionaliteit yaitu tidak semua alat dapat dipakai, hanya yang masuk akal. Karena terdapat pembelaan yang dilakukan harus sesuai dengan serangan yang bersifat melawan hukum, sedangkan pembelaan diri harus disebabkan terpaksa karena tidak ada jalan lain. Jadi, dalam membuktikan suatu kasus hakim harus benarbenar memperhatikan asas tersebut apakah merupakan alasan dalam noodweer atau bukan.

Menurut Profesor Pompe tentang sebab-sebab mengapa seseorang yang didalam suatu noodweeer telah melakukan suatu tindak pidana itu tidak dapat dihukum, alasannya bahwa apa yang telah ia lakukan itu adalah merupakan haknya, yakni hak nya yang bersifat alamiah untuk melakukan pembelaan terhadap sesuatu yang melawan hukum dan bukan merupakan kewajiban sebagaimana yang telah ditentukan di dalam pasal-pasal 50 dan 51 KUHP (Lamintang, 2014).

Jadi, pembelaan diri merupakan hak yang diberikan oleh undang-undang dan merupakan tugas kewajiban untuk mempertahankan diri atau hartanya dan masyarakat tidak memperoleh keuntungan atau tidak ada kemaslahatan dalam menjatuhkan hukuman atas orang yang membela diri karena ia bukan pembuat kejahatan. Dalam suatu peristiwa serangan yang terjadi dalam pembelaan terpaksa, maka harus dilihat dengan cermat dan teliti, terlihat disini bahwa rasa keadilanlah yang harus menentukan sampai dimanakah keperluan noodweer dibutuhkan yang menghalalkan perbuatan yang bersangkutan terhadap seorang penyerang.

Menurut Profesor Pompe, masalah ada tidaknya pertanggungjawaban pidana diputuskan oleh hakim, menurutnya dapat dipertanggungjawabkan itu berkaitan dengan kesalahan. Orang dapat menyatakan dapat dipertanggungjawabkan itu sendiri merupakan kesalahan. Menurut Pompe selanjutnya dapat dipertanggungjawabkan bukanlah merupakan bagian inti tetapi tidak dapat dipertanggungjawankan itu merupakan dasar peniada hukuman atau hapusnya hukuman (Hamzah, 2004).

Perbuatan yang dilakukan dalam pembelaan terpaksa harus perbuatan yang seimbang dengan bahaya atau ancaman serangan, adanya keseimbangan itu sangat penting agar seseorang yang melakukan pembelaan tidak melebihi batas perbuatannya dalam melindungi dirinya dari serangan. Dengan perubahannya hukum yang dahulunya pada abad18 keadaan pembelaan terpaksa hanya membolehkan seseorang membela dirinya sendiri tetapi pada masa sekarang pembelaan terpaksa tidak hanya membela dirinya sendiri tetapi juga membela orang lain. Rasa keadilan harus selalu ditegakkan dalam memberikan hukuman, keadilan menghendaki agar sesuatu hukuman harus sesuai dengan besarnya kesalahan pembuat dan hakim harus teliti dalam menjatuhkan hukumannya.

\section{KESIMPULAN}

Tindak pidana pembunuhan dalam pembelaan terpaksa, menjelaskan suatu tindak pidana pembunuhan yang sudah jelas pada akhirnya memiliki sanksi yang berat, baik itu hukum pidana Indonesia. Maka dari itu dengan adanya keterpaksaan atau dorongan daya 
paksa yang menjadi alasan penghapus tindak pidana dalam memunculkan suatu tindak pidana pembunuhan apakah pada akhirnya dihukumi menjadi suatu alasan pembenar ataukah pemaaf dalam hukum pidana Indonesia.

Dalam hal tersebut sebenarnya pelaku sudah memenuhi semua unsur tindak pidana yang dirumuskan dalam peraturan pidana. Akan tetapi ada beberapa alasan yang dapat menyebabkan pelaku tidak dipidana, atau dikecualikan dari penjatuhan sanksi pidana sebagaimana yang telah dirumuskan dalam peraturan perundnag-undangan dan ini merupakan kewenangan yang diberikan undang-undang kepada hakim.

\section{DAFTAR PUSTAKA}

Abidin Farid, Z. (2007). Hukum Pidana I. Jakarta: Sinar Grafika.

Hamzah, A. (2004). Asas-Asas Hukum Pidana. Jakarta: Rieneka Cipta.

Hutabarat, R. (1985). Persamaan Di Hadapan Hukum "Equality Before The Law" Di Indonesia (1st ed.). Jakarta: Ghalia Indonesia.

Julaiddin. (2018). of Swara Justisia. UNES Journal of Swara Justisia, 2(1), 74-88. R

Julaiddin \& Sari, H. P. (2019). Citizen Lawsuit (Gugatan Warga Negara) Terhadap Penyelenggara Negara Dalam Mencari Keadilan. Unes Journal of Swara Justisia, 1(1), 13-23.

Lamintang, P. A. F. (2014). Dasar-Dasar Hukum Pidana Di Indonesia. Bandung: P.T. Citra Aditya Bhakti.

Moeljatno. (1993). Perbuatan Pidana dan Pertanggung jawaban Dalam Hukum Pidana. Jakarta: Bina Aksara.

Prodjodikoro, W. (2003). Asas-Asas Hukum Pidana di Indonesia. Bandung: Eresco. 